\title{
TOWARDS INTEGRATION OF LADM AND CITYGML FOR THE CADASTRAL SYSTEM OF TURKEY
}

\author{
H.G. Surmeneli ${ }^{a}$, M. N. Koeva ${ }^{\text {b*, J. A. Zevenbergen }}{ }^{\text {b }}$, M. Alkan ${ }^{a}$ \\ ${ }^{a}$ YTU, Civil Engineering Faculty, Dept. of Geomatic Engineering, 34220 Esenler Istanbul, Turkey - (hsurmen, alkan)@ ytu.edu.tr \\ ${ }^{\mathrm{b}}$ Faculty of Geo-Information Science and Earth Observation (ITC), University of Twente, Enschede, the Netherlands - (m.n.koeva, \\ j.a.zevenbergen)@utwente.nl
}

Commission IV, WG 10

KEY WORDS: LADM, CityGML, 3D Cadastre, 3D City Modelling, 3D Data Model

\begin{abstract}
:
With the rapid urbanization and the dynamics in land transactions, Turkish cadastre, as in many other countries, is facing challenges in the daily recording of sales, donations, taxations, and mortgages on land. Especially with the modern constructions and complex interrelationships of rights, restrictions, and responsibilities (RRR), the third dimension should not be forgotten. In this context, the design of a new cadastre data model for Turkey is essential. Inspired by this need, with this study, we aim in proposing a new cadastre model based on international standards such as Land Administration Data Model (LADM) and CityGML. LADM represents the legal and administrative aspects of the cadastral objects but does not show the semantic and 3D geometrical representation of physical cadastral objects which are required for the process of 3D cadastre. Therefore, in the paper, we propose an Application Domain Extension (ADE) for the cadastral objects that expands the integration of LADM and CityGML data model with the legal and administrative concepts defined in the Turkish Law. The study presents a detailed overview of the Turkish legal cadastre system and a proposal for its physical realization based on international standards. In addition, the developed ADE is also valuable for cadastral services undertaken by the General Directorate of Land Registry and Cadastre (GDLRC). It could also be used as a basis of a 3D national data standard for cadastral information systems.
\end{abstract}

\section{INTRODUCTION}

From the late 1990s onwards, the work on 3D Cadastre has developed all over the world. International studies on future cadastral systems have been investigated e.g Cadastre 2014 (Steudler, 2014) and 2034 (ICSM, 2015Aien, 2013; Stoter, 2004; Alkan et al., 2018). Within the scope of Cadastre 2034 vision, the cadastral system of the future should include all rights, restrictions and responsibilities (RRR) related to real estates with advanced policies, standards and models. Institutions and scientists have intensively studied the concept of threedimensional immovable properties in the last decade (Fendel, 2002; Stoter and Van Oosterom, 2006; Ploeger, 2011; Stoter et al., 2012; Van Oosterom, 2013; Paasch and Paulsson, 2014; Kitsakis et al., 2016). As a result of these studies, different topics have come up within the context of 3D cadastre. These are listed in the five main headings in FIG publication (Van Oosterom, 2018).

- Legal foundations for 3D Cadastre

- Initial Registration of 3D Parcels

- 3D Cadastral Information Modelling

- 3D Spatial DBMS for 3D Cadastres

- Visualisation and New Opportunities

According to some researchers, the 3D cadastre should be a system where rights, restrictions, responsibilities (legal models) of buildings and properties are corresponding to their physical models (provision of registered rights above and below the $3 \mathrm{D}$ terrain surface) (Stoter, 2004; Papaefthymiou et al., 2004; Aien, 2013). In this way, 3D cadastre facilitates the management of property rights in the real world. Having well created and maintained 3D cadastre will be beneficial for many other applications which require integration of legal and physical model of the objects of interest. Such applications can be urban planning, land and property management, etc. (Rajabifard et al., 2018). Moreover, cadastre can be integrated with other information such as 3D city models such as CityGML, Building Information Model (BIM), transportation, service networks, land use, etc. (Aien, 2013). In addition, LandInfra, which is relatively new and is an open standard from the OGC for land and civil engineering infrastructure facilities, is focused on land, including roads, buildings, railways, alignments, surveys, land features and land divisions. (Kumar et al., 2019; Scarponcini et al., 2016).

Exploring the examples from 3D Cadastre worldwide, we found a lot of similarities. The proposed solutions are similar, even different aspects of 3D features are taken into account, based on the structure of their cadastral systems, the types of recorded objects, etc. There are regulations in Australia (Aien, 2013) and Canada (Stoter and Van Oosterom, 2006), which contain detailed explanations on how to measure and register a parcel in 3D. The Netherlands changed the Civil Law on Cadastre in 2007, thus redefining the ownership of land, which lead to a registration of 3D objects determined by the law independently from the parcel (Wakker et al., 2003). In the Netherlands and Switzerland, there is a separate Line cadastre for the recording of underground networks (Wakker et al., 2003; Steudler, 2015). In Norway, the registration of underground structures is not mandatory and is

\footnotetext{
* Corresponding author
} 
made optional (Herdlevær, 2018). In Switzerland, studies have been carried out to convert the existing cadastral database into a 3D state. For the Swiss Cadastre, a comprehensive plan covering the transition to 3D cadastre was prepared (Steudler, 2015). In some countries, the whole cadastre is already digital, however, there are still countries that are continuously working in this direction, such as Greece. (Van Oosterom et al., 2018). In China, there is no integrated cadastral system (Guo et al., 2013). In Switzerland, studies have been carried out to convert the existing cadastral database into 3D Cadastre. For Switzerland, a comprehensive plan covering the transition to $3 \mathrm{D}$ cadastre was prepared (Steudler, 2015). On the other hand, the Queensland and Victoria states of Australia have shown great interest in the ongoing studies of 3D real estate in the 3D cadastral area (Aien, 2013; Shojaei et al., 2016).

Inspired by the international development and defined standards, the current research aims to support the regulation and analysis of 3D land rights, restrictions, and responsibilities for the Turkish Cadastre System. We used Cadastre 2014 (Steudler, 2014), 2034 Vision (ICSM, 2015) of INSPIRE and ISO 19152 (ISO, 2012), Land Administration Domain Model (LADM), and developed an innovative 3D data model for Turkey based on these internationally accepted standards. In the current research, we share our two main outputs: 1) innovative 3D legal model for the Turkish cadastral system and 2) new proposed model for the Turkish cadastral system using, LADM and CityGML combining legal and physical model

The remaining of this paper covers the background of Turkish cadastral systems, the methodology of the study followed by results, discussion, and conclusion.

\section{BACKGROUND OF THE TURKISH CADASTRAL SYSTEM}

Turkish cadastre consists of two parts: land registry that represents the legal relationship between people and real properties, and the cadastral maps that, besides geometry data and annotations, contain the land-use. At the same time, it keeps the temporal information about the land registry records. However, this information is stored independently from the geometry as a separate attribute.

According to Article 718 of the Civil Code (TMK, 2001), the scope of the utility, in practice, is related to the intended use of the property. For example, power lines on a building endanger and restrict the use of the building. Another example related to metro lines is that if they are passing over the road they are not registered in the cadastre however, if they are within a private property, they are registered and have certin restrictions. The third dimension is not sufficiently covered in the constitution. However, there are several rights set out in the Turkish constitution with respect to the third dimension (e.g., easement right). The cadastral system in Turkey was evaluated based on the Cadastre 2014 (Steudler, 2014) and 2034 (ICSM, 2015) visions following the criteria selection as done in the cadastral book (V. Oosterom et al., 2018).

Land Registry and Cadastre in Turkey have encountered numerous problems in the past, such as storing data in multiple places and organizations, some in analog other in digital form. Quite some records have significant discrepancies with respect to the actual situation, and in general, the information is outdated and stored in a variety of formats. However, recently there is significant progress. Many analog cadastral maps have been converted to digital form by the General Directorate of Land Registry and Cadastre (GDLRC) and are available in a shared database. Also, the cadastral system and cadastral data have been improved due to work on many projects aiming in integration and new vision for the Turkish cadastre. Such projects are, so-called in Turkish TUCBS which means Turkey National Spatial Data Infrastructure and TAKBIS, which is Land Registry and Cadastre Information System (Nișancı and Özçelik, 2015) (Table1). The aim of TAKBIS project is to create the Turkish Land Registry and Cadastre Information System across the whole country. TUCBS is an e-government project aiming at establishing the infrastructure for Geographical Information System following the technological developments at the national level (Turkish National Geographic Information System-TUCBS).

In this context, the cadastral systems of the countries described in the introduction were examined. Evaluation of Turkish cadastral system within the scope of 3D Cadastre is shown in table 1, according to which the laws of the cadastral object to be registered in the cadastral system in Turkey. The criteria determined in table 1 . were obtained from the studies conducted in the cadastral book (V. Oosterom et al., 2018).

\section{METHODOLOGY}

To achieve the aim of the current study the following steps were followed (Figure 1):
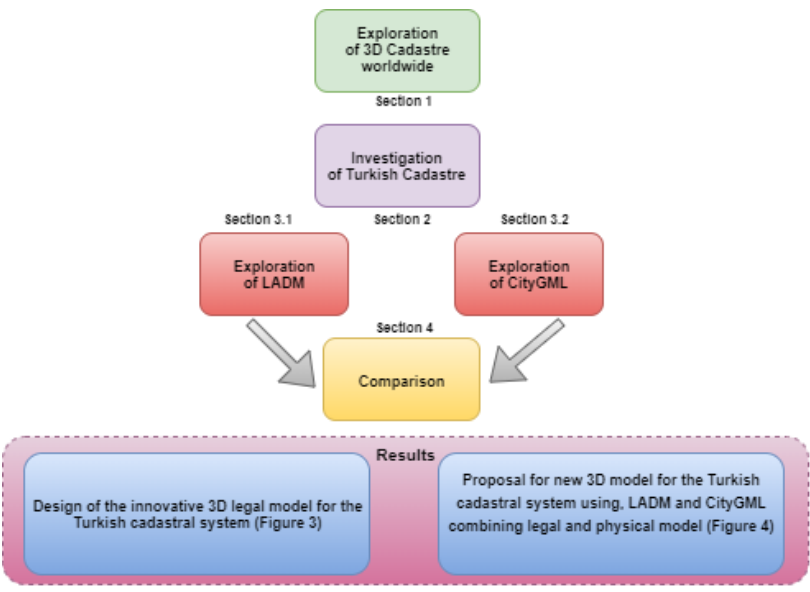

Figure 1. Methodology.

\subsection{Land Administration Domain Model (LADM, ISO 19152)}

The land administration domain model is developed to contribute to Land Administration Systems (LAS). The basic principle is that the use of ISO standards and OGC standards and the model must be simple (Steudler and Kaufmann, 2002). The land administration domain model has been established by ISO/TC211 with the aim of standardizing geographical information and geo-characteristics (Van Oosterom et al, 2006). The main objectives of the LADM are:

- Establishing an ontology shared with the model

- Supporting the development of applied software for land administration

- Facilitate the exchange of cadastral data with the shared land administration system 
- Support for quality data management in land management

(Oosterom et al, 2013).

\begin{tabular}{|c|c|c|c|c|c|c|c|c|}
\hline General Information & $\begin{array}{c}\text { Status of 3D Object } \\
\text { Recording }\end{array}$ & $\begin{array}{l}\text { Rights that can } \\
\text { be registered } \\
\text { in 3D }\end{array}$ & $\begin{array}{c}\text { The legal } \\
\text { definition of the } \\
\text { 3D objects }\end{array}$ & $\begin{array}{l}\text { Registered } \\
\text { 3D objects }\end{array}$ & $\begin{array}{c}\text { Presentati } \\
\text { on of 3D } \\
\text { objects to } \\
\text { cadastral } \\
\text { map }\end{array}$ & $\begin{array}{c}\text { Type of } \\
\text { cadastral } \\
\text { parcel } \\
(2 \mathrm{D} / 3 \mathrm{D})\end{array}$ & $\begin{array}{c}\text { Projects } \\
\text { related to } \\
\text { cadastre }\end{array}$ & $\begin{array}{c}\text { Models } \\
\text { related to } \\
\text { 3D/4D } \\
\text { Cadastre }\end{array}$ \\
\hline - Civil law & - $2 D$ registration of & - Land, Parcel, & - Registration of & -Buildings & & & $-3 D$ & \\
\hline - The right to property & $3 D$ objects & Buildings, & $3 D$ objects is & and annex & & & Cadastre & \\
\hline guarantee & and rights are & sections, and & easements & -Easement & & & - TUCBS & \\
\hline - Title Law & registered & Annex are & - The type, scope, & Condominium & & & - MEGSIS & \\
\hline - Cadastre Law & - Condominium & registered & and application of & - High voltage & & & & \\
\hline - Title registration & registration & - RRRs on & 3D RRRs are & lines & & & & \\
\hline system & - Registration is & registered & defined in the & - Oil and & & & & \\
\hline - Cadastral maps in & mandatory & objects are & Civil and & Natural Gas & & & & \\
\hline - Complete all cadastre & registered as & - Registered & - The law does not & - Pylon & & & & \\
\hline across the country & easement & RRRs are & have the & locations & & & & \\
\hline - Underground & - Easements are & represented in & necessary & - Water & & & & \\
\hline structures are not & represented in $2 D$ on & $2 D$ & explanations to & channels & & & & \\
\hline registered & the cadastral map & & register $3 D$ & & & & & \\
\hline $\begin{array}{l}\text { - Cable, water, sewage, } \\
\text { and telecommunication }\end{array}$ & $\begin{array}{l}\text { - Architectural plans } \\
\text { include } 3 D\end{array}$ & & objects & & & & & \\
\hline $\begin{array}{l}\text { lines are not recorded } \\
\text { - Condominium }\end{array}$ & information & & & & & & & \\
\hline
\end{tabular}

Table 1. Evaluation of Turkish cadastral system within the scope of 3D cadastre

The three-dimensional cadastre is a cadastre that provides information on the rights, restrictions, and responsibilities on registration and not only on the parcel but also the $3 \mathrm{D}$ possessive units (Stoter, 2004). In this context, the Basic Model of Land Administration constitutes a basic class in order to define the rights, restrictions and responsibilities concerning the $3 \mathrm{rd}$ dimension of the real estate.

The main starting point of the LADM is to establish a common ontology for rights, restrictions and responsibilities affecting the land administration and its geometric components. Thus, it will enable communication between related parties within a country or between different countries (Van Oosterom et al., 2006; Lemmen et al., 2015). The LADM is developed in line with the Cadastre 2014 vision and complies with international ISO and OGC standards (Lemmen et al., 2009; Lemmen et al., 2011; Tjia and Coetzee, 2013). Besides, it has been conducted in the studies showing the compatibility of LADM with INSPIRE (Alkan and Polat, 2017). LADM has three main packages and one subpackage. These are LA_Party (Party package), LA_AdministrativePackage (Management package) and LA_SpatialUnitPackage (Spatial Unit package) and LA_SurveyingAndRepresentation (Figure 2).

It also supports the time component of the Land Administration Basic Model. The most important feature of the model is that it is a flexible model and can be expanded within specified standards. It is possible to associate with external classes such as Valuation, Address, and the Landcover as required by the model feature.

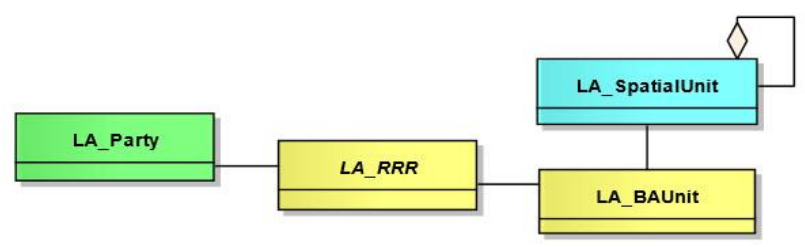

Figure 2. Basic packages of LADM (ISO19152).

\subsection{A General Overview of CityGML}

CityGML is a semantic information model represented in an XML-based format to facilitate the exchange, sharing, storage, and maintenance of the virtual 3D city models. It is an application schema for the GML version 3.1.2 (GML3), and an extendable international standard for spatial data exchange issued by the Open Geospatial Consortium (OGC). CityGML provides a comprehensive representation of the basic entities, attributes, and relations of a 3D city model in terms of their geometry, topology, semantics, and appearance. (Çağdaş, 2013; Rönsdorf et al., 2014; Zadef et al., 2019). CityGML data model has two modules. These are the core module and the thematic extension modules. The core module is composed of the basic concepts and components of the CityGML data model. The extension modules comprise specific thematic fields of the virtual 3D city model such as Appearance, Bridge, Building, CityFurniture, CityObjectGroup, Generics, LandUse, Relief, Transportation, Tunnel, Vegetation, WaterBody, and TexturedSurface (OGC, 2012). CityGML is mostly utilized to structure and represent physical part such as walls, roofs, curbs or vegetation objects, 
whereas the representation of legal extents is not explicitly mentioned in the standard, but can be implemented using Application Domain Extensions (ADEs) (Zadef et al., 2019). ADE is applied for CityGML adaptation to non-standard requirements of specific application areas. It enables the definition of new feature types, attributes, geometries, and associations (Çağdaş, 2013).

CityGML allows multiple representations of the city objects based on five different level-of-details (LOD). LOD1 provides the block model, without any roof structures. LOD2 is the block model with roof structures, texture and larger building installations. LOD3 provides detailed architectural models. Finally, LOD4 enriches LOD3 by adding interior structure objects (OGC, 2012). CityGML implements a subset of the ISO19107 geometry model. It also allows selection between geometric representations and direct expressions via GML data types. Implies re-use and representation through X-links (Stoter et al, 2014). Some feature classes in CityGML are:

- The CityGML Building Module: Representation of a physical building in different Levels of Detail. The main class in Building module is AbstractBuilding, which is either a BuildingPart or a Building.

-_CityObject: The base class of all objects is_CityObject which is a subclass of the GML class _Feature. All objects inherit the properties from_CityObject.

- Landuse: defines land areas of particular use and could be used to represent parcels or ownership. The LandUse class has the attributes class, function and usage. The class attribute is used to represent the classification of land use objects, such as settlement areas, industrial areas and farmland. The attribute function defines the purpose of the object, for example, a cornfield, while the attribute usage can be used, if the object is used in a way that differs from the function (Çağdaş, 2013; Rönsdorf et al., 2014; OGC, 2012).

\section{INTEGRATION OF LADM AND CITYGML FOR THE TURKISH CADASTRE}

\subsection{Turkey Cadastral Profile based on LADM}

The research was performed using the following steps: analysis of the requirements defined in Turkey Law and the institutional studies; analysis of the international standards in the field of the research and literature review; analysis of the current cadastral information system. After the analysis a comparison with LADM was done and an innovative 3D legal model for the Turkish cadastral system is roposed and is shown in Table2. Therefore, new domain model was proposed as an implemetnation of LADM classes for the Turkish cadastral conceptual model. (Figure 3).

Table 2 shows the comparison of LADM classes, and the proposed new 3D conceptual data model classess. These are: Party, Administrative, Spatial Unit and Surveying and Representations Packages respectively. The LA_Package describes the owners, right holders. LA_SpatialUnit Package describes spatial units (e.g. parcel, building, apartment) and was mapped to the abstract class RealEstate. LA_RRR describes the rights, restrictions, and responsibilities over the property. The LA_BAUnit class represents a basic administrative unit, which is a set of rights, restrictions, and responsibilities of one or more real properties. In the conceptual model for Turkey, this is equivalent to the RegistrationObject. Surveying and Representation classes are TR_Point, TR_SpatialSource, and TR_BoundaryFaceString.

After the analysis of requirements for Turkey, proposed implemetnation of LADM classes for the Turkey cadastral conceptual model within the scope of the ISO 19152 was done (Figure 3).

The model consists of 4 basic classes (TR_Party - in green color in Figure3, TR_RRR, TR_RegistrationProcess and TR_RegistrationObject - in yellow color in Figure3) and 24 subclasses such as TR_Right, TR_Representation, TR_GeometryProcess, TR_Point. Rights, Responsibility and Restrictions is a package in which real or legal persons can represent relationships status on a real estate (Figure 3). The TR Right class is divided into two sub-classes as property rights and limited rights. The right to property is the right of owner or legal persons to make all kinds of operations, such as the use of property, purchase, sale, rent, etc. The limited real rights class is divided into two sub-classes as mortgage and easement. The restriction class is the part of the information that restricts the use of limited real rights in the title registration, where the restriction information is registered, and the information is determined. These restrictions are subdivided into representations, rights and liability, annotations and mortgages in the land register. In this class person's obligations are represented. These obligations include pauing the tax on the real estate, maintenance, repair, easement according to the type of real estate. There may be one or more types of obligations.

TR_RegistrationProcess class has 3 sub-classes. These are TR_GeometryProcess, TR_LandUseConversion and TR_PropertyProcess (in yellow color in Figure3). Geometry process shows processes such as subdivision, amalgamation and land subdivision. The class of property process consists of transactions, such as sales and gratuity, which result in changes not only in the geometry of the property but also in its ownership. The land use conversion process class only includes changes that occur in the type of real estate.

The SpatialUnit class (in blue color in Figure3) is the parent class in which all cadastral objects are represented and associated with the other classes. The SpatialUnit class comprises parcel subclasses, buildings and independent sections. The parcel class is obligatory for the cadastral system. The building class has a composition relation type with the parcel class. So every building must be on a parcel. The condominium is considered a spatial unit. A building can have non or more independent parts. According to the Property Law, the Annex is outside of a condominium. Also, it is referred to directly as allocated to that section. The Annex cannot be registered alone in the land register. Therefore, the type of $0 .{ }^{*}$ (0-lots) relationship is selected between the condominium and Annex. Utility network, electricity, telephone, drinking water, sewerage, natural gas facilities are called technical infrastructure 


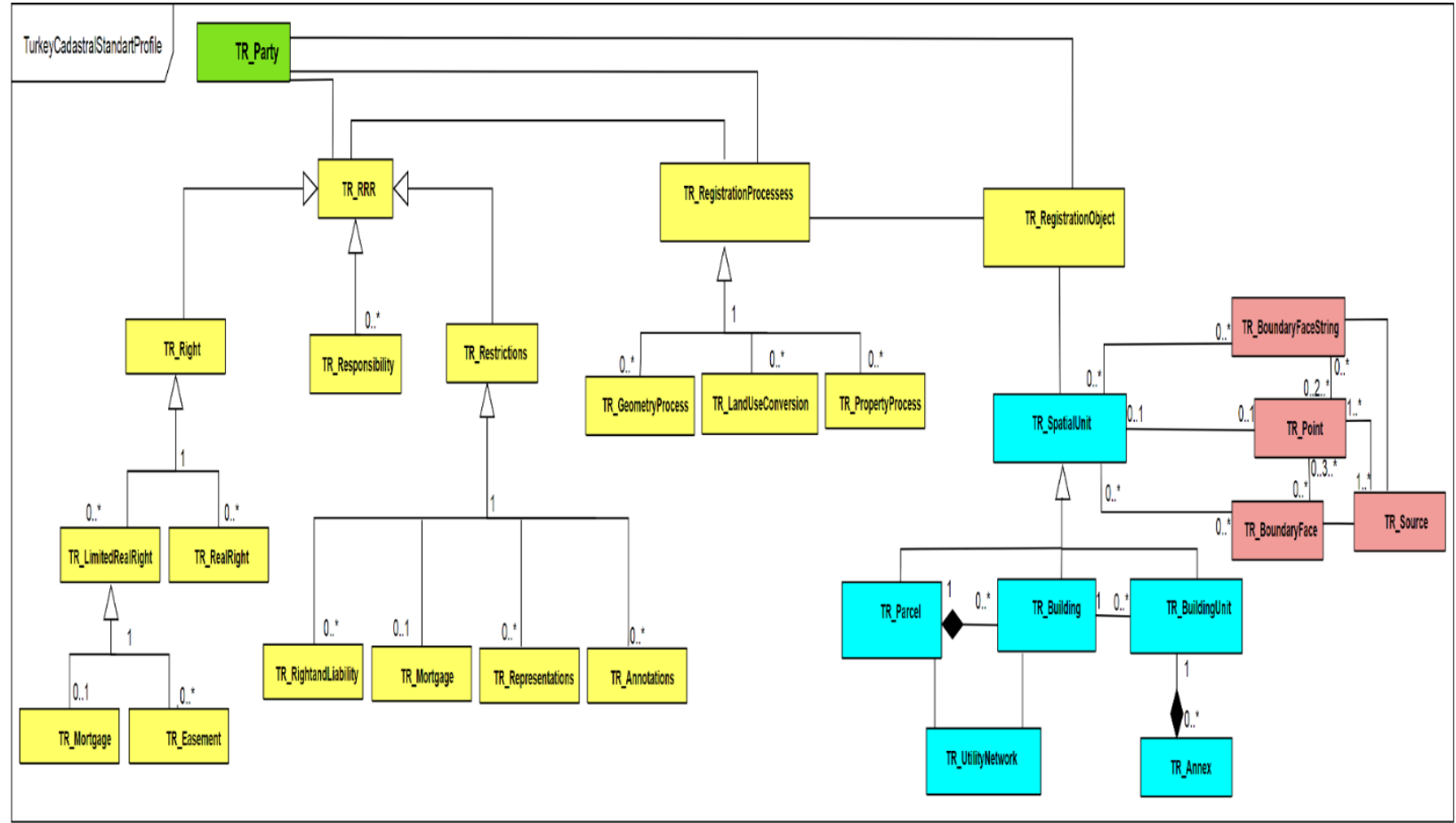

Figure 3. Proposed implemetnation of LADM classes for the Turkish cadastral conceptual model

facilities. In the existing cadastral system in Turkey, utility networks are not registered to the land registry. The existence of a utility network is associated with the parcel or building. In addition, there may not be any utility network equipment under or above each parcel and building. Therefore, the UtilityNetwork class has a type of $0 . .^{*}$ ( 0 and many) relationships with structure and parcel class. Since the land registry is not registered, data related to the utility network facility cannot be kept directly in the system. Also, it can be provided with external class TR_ExternalUtilityNetwork.

Finally, the survey and representation sub-package (in red color in Figure3), is the package in which the spatial objects and the geometric status are represented together with the rights, restrictions and responsibility processes. The package represents geographic points, 2D and 3D borders, title and other resources. The attributes of the classes in the package have been created following the INSPIRE and LADM standards.

\begin{tabular}{|c|c|c|}
\hline Turkey Legislation Profile & LADM Class & 3D Conceptual Data Model Classes \\
\hline \multicolumn{3}{|c|}{ Party Package } \\
\hline Parties & LA_Party & TR_Party \\
\hline Undefined & LA_GroupParty & TR_GroupParty \\
\hline Undefined & LA_PartyMember & TR_PartyMember \\
\hline \multicolumn{3}{|c|}{ Administrative Package } \\
\hline Undefined & LA_RRR & TR_RRR \\
\hline Rights & LA_Right & TR_Right \\
\hline Restrictions & LA_Restriction & TR_Restriction \\
\hline Responsibility & LA_Responsibility & TR_Responsibility \\
\hline Easement & LA_Right & TR_Easement \\
\hline RightofTimeshare & LA_Right & TR_Right \\
\hline RegistrationObject & LA_BAUnit & TR_BAUnit \\
\hline Restrictions & LA_Mortgage & TR_Mortgage \\
\hline Documents & LA_AdministrativeSource & TR_AdministrativeSource \\
\hline- & LA_RequiredRelationshipBAUnit & TR_RequiredRelationshipBAUnit \\
\hline \multicolumn{3}{|c|}{ Spatial Unit Package } \\
\hline RealEstate & LA_SpatialUnit & TR_SpatialUnit \\
\hline Parcel & LA_SpatialUnit & TR_Parcel \\
\hline PartOfParcel & LA_SpatialUnit & TR_PartOfParcel \\
\hline Building & LA_SpatialUnit & TR_Building \\
\hline ProjectSite & LA_SpatialUnitGroup & TR_SpatialUnitGroup \\
\hline Condominiums & LA_LegalSpaceBuildingUnit & TR_LegalSpaceBuildingUnit \\
\hline Pipeline & LA_LegalSpaceUtilityNetwork & TR_LegalSpaceUtilityNetwork \\
\hline- & LA_Level & TR_Level \\
\hline- & LA_RequiredRelationshipSpatialUnit & TR_RequiredRelationshipSpatialUnit \\
\hline \multicolumn{3}{|c|}{ Surveying and Representations Subpackage } \\
\hline & LA_Point & TR_Point \\
\hline Documents & LA_SpatialSource & TR_SpatialSource \\
\hline Boundary & LA_BoundaryFaceString & TR_BoundaryFaceString \\
\hline 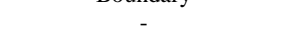 & LA_BoundaryFace & \\
\hline
\end{tabular}

Table 2. Comparison of LADM classes with the proposed new 3D conceptual data model classess. 


\subsection{Integration of LADM and CityGML}

In this section we analyse the differences and similarities between CityGML and LADM using some of the criteria derived from (Kumar et al., 2019; Zadef et al., 2019, Rönsdorff et al., 2014). These are briefly summarised in Table 3 .

\begin{tabular}{|c|c|c|}
\hline Criteria & CityGML & $L A D M$ \\
\hline Body & $O G C$ & $I S O$ \\
\hline User & $\begin{array}{l}3 D \text { City } \\
\text { Modellers }\end{array}$ & Survey Engineers \\
\hline Focus & City objects & $\begin{array}{l}\text { Land } \\
\text { administrations }\end{array}$ \\
\hline Purpose & $3 D$ City Models & $\begin{array}{l}\text { Land } \\
\text { administrations } \\
\text { and cadastral legal } \\
\text { models }\end{array}$ \\
\hline Land use & Simple types & LADM types \\
\hline Semantic & Detailed & Not supported \\
\hline $\begin{array}{l}\text { Thematic } \\
\text { scope }\end{array}$ & $\begin{array}{l}\text { Building, Utility } \\
\text { network, City } \\
\text { objects, Road, } \\
\text { Energy }\end{array}$ & $\begin{array}{l}\text { Cadastre and } \\
\text { Surveying }\end{array}$ \\
\hline Model & Physical model & Legal model \\
\hline$L O D s$ & $\begin{array}{l}5 \text { differents } \\
\text { LODs }\end{array}$ & Not supported \\
\hline Geometry & $3 D$ & $2 D$ \\
\hline
\end{tabular}

Table 3. Comparing CityGML with LADM.

As briefly introduced above, CityGML is standardised by OGC while ISO has standardized LADM. Also, LADM focuses on cadastral objects while CityGML focuses more on city objects. Through both its modules and extensions, CityGML provides substantial coverage at the urban scale of buildings, utility networks, energy and hydrology. Also, it has 10 thematic modules such as Bridge, Tunnel, CityObjects, etc. In addition, CityGML can be extended by the user community for more specialist domains through the Application Domain Extension (ADE) mechanism. Both CityGML and LADM were modelled in the Universal Modelling Language (UML).

In this context, different studies have been done on LADM and CityGML integration. Some studies propose two options for constructing an LADM-based ADE for CityGML standard. The first option is to create a specific profile of LADM and then implement this profile of LADM as an ADE of CityGML. The second one is to directly implement the fundamental concepts inside LADM (Rönsdorff et al., 2014; Gózdz et al. 2014; Li et al. 2016; Çağdaş, 2013).

For the current study for Turkey, we implemented the first option. First, legal model was created using LADM for the cadastral data of Turkey as described in section 4.1. Afterwards, CityGML ADE extension was used to represent the physically cadastral objects. Thus, the proposed new 3D cadastral data model which combines both legal and physical model was done (Figure 4).

As mentioned above, CityGML does not provide representation of property units with cadastral parcels and condominium units.
So, in the developed ADE, three new feature classes; TR_PhyscalObject, TR_Building and TR_Land were added. Conceptually, the TR_PhyscalObject is an abstract class with two concrete classes TR_Building and TR_Land. TR_Building and TR_Land have already been associated with BuildingUsePart, LandUse and Building, Parcel subclasses of LADM (Figure4). The TR_Land are not clearly represented with CityGML, but the OGC specification states that the LandUse class can be used to represent cadastral parcels in 3D (OGC, 2012). The TR_Land class is also associated with the LADM parcel class. Thus it inherits the parcel attributes. Therefore, a new feature class is created TR_Land which is a subclass of the CityGML LandUse. The TR_Land inherits all attributes and relations from the CityGML LandUse. Moreover, it applies to the TR_Bulding class in the same way.

This section has explained the development of an ADE to CityGML for the 3D cadastral data model for Turkey. It also showed how the legal and administrative concepts in LADM are integrated with the physical objects specified in the CityGML. The CityGML provides a flexible conceptual model which can easily be adapted to administrative and physical requirements. The research reveals that the CityGML data model which is supported with legal concepts has the potential to be a national data model for 3D cadastre in Turkey

\section{DISCUSSION}

With the development of the modern technology and urban complexities, the 2D cadastre is no longer sufficient. In this context, international standards (LADM, LandInfra, CityGML etc.) have been created. In line with these standards, many studies have been conducted in many countries. In Turkey, there are not enough scientific studies on 3D cadastre. The studies carried out within the scope of 3D cadastre generally aim at analyzing the cadastral situation of the country, examining the use of easement rights and legal regulations arising from the third dimension and presenting sample database designs for local cadastral installation. In this context, two important outputs were developed for this study. The first one is innovative 3D legal model for the Turkish cadastral system and the second one is new proposed model for the Turkish cadastral system using, LADM and CityGML combining legal and physical model.

\section{CONCLUSION}

To propose new legal 3D conceptual data model the similarities and differences between LADM and the Turkish cadastral system were analysed. This analisys contributes for developing national standard for 3D cadastral system. Therefore, to combine the legal and physical part an investigation on integration of LADM and CityGML has been done. The result is a developed ADE which is of value for GDLRC and can be used as a basis of a 3D national data standard. Moreover, it can contribute for establishment of spatial data infrastructure in Turkey and can be internationally recognised. 


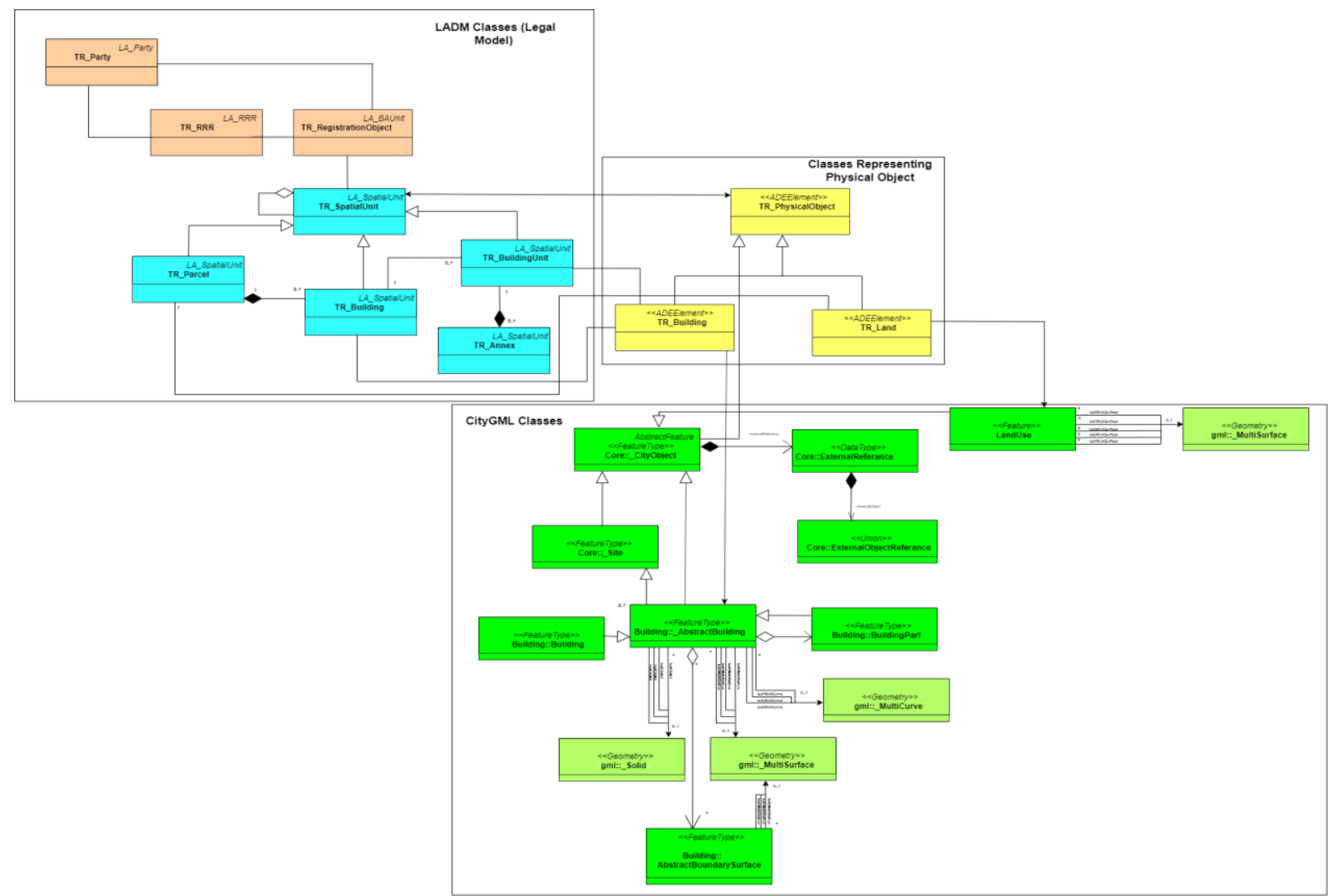

Figure 4. New proposed model for the Turkish cadastral system using, LADM and CityGML combining legal and physical model

\section{REFERENCES}

Aien, A., 2013. 3D Cadastral data modelling. PhD Thesis, Melbourne University, Victoria, Australia.

Alkan, M. and Polat, Z.A., 2017. Design and development of LADM-based infrastructure for Turkey. Survey Review, 49:356, 370-385.

Alkan M., Gürsoy Sürmeneli H., Polat Z.A., 2019. Design and determine cadastral and land management performance of Turkey with Cadastre 2034 Vision. XXVI FIG Congress, Istanbul, Türkiye, 6-11 May.

Aydınoğlu A.Ç. and Bovkir R., 2017. Generic land register and cadastre data model supporting interoperability based on international standards for Turkey. Land Use Policy, 68, 59-71.

Çağdaş, V., 2013. An application domain extension to CityGML for immovable property taxation: A Turkish case study. International Journal of Applied Earth Observation and Geoinformation, 21, 545-555.

Fendel, E., 2002. Registration of properties in Strata. Report on the working sessions. International workshop on 3D Cadastres, Delft, the Netherlands.

Guo, R., Li, L., He, B., Luo, P. Ying, S., Ziang, R., 2013. Developing a 3D cadastre for the administration of urban land use: A case study of Shenzhen, China. Computers, Environment and Urban Systems, 40, 46-55.
Gózdz, K., Pachelski, W., Van Oosterom, P.J.M., and Coors, V., 2014. The possibilities of using CityGML for 3D representation of buildings in the cadastre. In: Proceedings 4th International Workshop on 3D Cadastres, 9-11 November 2014, Dubai, United Arab Emirates. International Federation of Surveyors (FIG), 339-362.

Herdlevær, H., 2018. Cadastral template. Norwegian Mapping and Cadaster Authority Director Cadastral Department.

Kitsakis, D., Apostolou, C. and Dimopoulou, E., 2016. Three dimensional cadastre modelling of customary real estate rights. Survey Review, DOI: 10.1080/00396265.2016.1252518

Lemmen, C., Van Oosterom, P., Uitermark, H., Thompson, R., and Hespanha, J.P. 2009. Transforming the land administration domain model (LADM) into an ISO standard (ISO19152). FIG working week, Eilat, Israel. <http://www.gdmc.nl/publications/2009/LADM_to_ISO_Stand ard.pdf $>$.

Kumar, K., Labetski, A., Ohori, A. K.., Ledoux, H. and Stoter, J., 2019. The LandInfra standard and its role in solving the BIMGIS quagmire. Open Geospatial Data, Software and Standards, DOI: 10.1186/s40965-019-0065-z.

ICSM. , 2015. A Vision for Cadastre 2034.

ISO19152,2012. ISO 19152. International Standard, Geographic Information- Land administration domain model (LADM). 
Lemmen, C. H. J., Van Oosterom, P. J. M., Uitermark, H. T., Zevenbergen, J. A. and Cooper, A. K., 2011. Interoperable domain models: the ISO land administration domain model LADM and its external classes. UDMS 2011, Delft, The Netherlands, 28-30 September.

Lemmen, C., Van Oosterom, P. and Bennett, R., 2015. The land administration domain model. Land Use Policy, 49, 535-545.

Özçelik, A., 2013. Developing spatial data model for speciality agricultural crop lands: Case study on tea agriculture. $\mathrm{PhD}$ Thesis, Karadeniz Technical University Institute of Science and Technology, Trabzon.

Paulsson, J. and Paasch, J., 2014. 3D property research from a legal perspective. Computers, Environment and Urban Systems, $39(2)$.

Ploeger, H. 2011. Legal framework 3D cadastres position paper 1, In: van Oosterom, P., Fendel, E., Stoter, J., Streilein, A. (Eds.), 2nd International Workshop on 3D Cadastres, Delft, the Netherlands, 545-550, 16-18 November.

Scarponcini, P., Gruler, H.-C., Stubkjær, E., Axelsson, P., and Wikstrom, L., 2016. OGC Land and Infrastructure Conceptual Model Standard (LandInfra).

Shojaei, D., Olfat, H., Rajabifard, A., Darvill, A., Briffa, M. 2016. Assessment of the Australian digital cadastre protocol (ePlan) in terms of supporting 3D building subdivisions. Land Use Policy, 56, 112-124.

Steudler, D., 2015. Dimension cadastre - stepping beyond limits. Fig working Week 2015 From the Wisdom of the Ages to the Challenges of the Modern World Sofia, Bulgaria, 17-21 May.

Stoter, J. E. and Van Oosterom, P.J.M., 2006. 3D Cadastre in an international context: legal, organizational and technological aspects. Taylor \& Francis, CRC Press, 323 s. ISBN 0-84933932-4.

Stoter, J.E., 2004. 3D Cadastre. PhD thesis TU Delft, Publications on Geodesy 57, Netherlands Geodetic Commission, Delft, 327 p.

Stoter J.E. et al., 2012. 3D cadastre in the Netherlands: Developments and international applicability. Computers, Environment and Urban Systems, 40, 56-67.

Stuedler, D. and Kaufmann, J. eds. 2002. Benchmarking cadastral systems. FIG-commission 7 - Cadastre and land management working group 1998-2002 - Reforming the Cadastre, Meripaino Oy, Finland, April 2002.

Stuedler, D., 2014. CADASTRE 2014 and Beyond.

ISO 2012. ISO/FDIS 19152. Geographic Information - Land Administration Domain Model (LADM).

Lemmen, C. H. J. and Van Oosterom, P. J. M. 2013. The land administration domain model standard. 5th Land Administration Domain Model Workshop. Kuala Lumpur, Malaysia, 24-25 September.
Li, L., Wu, J., Zhu, H., Duan, X., and Luo, F., 2016. 3D modeling of the ownership structure of condominium units. Computers, Environment and Urban Systems, 59, 50-63.

Nişanci, R. and Özçelik, A. E. , 2015. An assessment towards to innovative cadastre integrated with cadastre 2034 vision. The World Cadastre Summit, Congress \& Exhibition. Istanbul, Turkey, 20-25 April.

OGC, 2012. City Geography Markup Language (CityGML) Encoding Standard.

Papaefthymiou M., Labropoulos, T., Zentelis, P. , 2004. 3D cadastre in Greece, legal, physical and practical issues. Application on Santorini Island, FIG Working Week 2004 Athens, Greece, May 22-27.

Rajabifard A., Atazadeh B. and Kalantari M., 2018. A critical evaluation of 3D spatial information models for managing legal arrangements of multiowned developments in Victoria, Australia. International Journal of Geographical Information Science, 32:10, 2098-2122.

Ronsdorf, C., Wilson, D. and Stoter, J., 2014. Integration of land administration domain model with CityGML for 3D cadastre. 4th International Workshop on 3D Cadastres 9-11 November, Dubai, United Arab Emirates.

Tjia, D. and Coetzee, S. , 2013. Application of the land administration domain model to the city of johannesburg land information system. South African Journal of Geomatics, 2(3), pp.260-79.

TMK, 2001. Turkish Civil Code.

Van Oosterom, P. J. M., Lemmen, C., Ingvarsson, T., van der Molen, P., Ploeger, H., Quak,W., Stoter, J. and Zevenbergen, J., 2006. The core cadastral domain model. Computers, Environment and Urban Systems, 30, pp.627-60.

Van Oosterom, P., Lemmen, C. and Uitermark, H., 2013. ISO 19152:2012, land administration domain model published by ISO. FIG Working Week 2013. Environment for Sustainability. Abuja, Nigeria, 6-10 May.

Van Oosterom, P.J.M., 2013. Research and development in 3D Cadastres, Computers, Environment and Urban Systems, 40, 1-6.

Van Oosterom, P.J.M., 2018. Best practices 3D cadastres extended version international federation of surveyors. Copenhagen, Denmark, March 2018 (ISBN 978-87-92853-64-6, ISSN: 2311-8423).

Zadeh, P. A., Wei, L., Dee, A., Pottinger, R. and Staub-French, S., 2019. Bim-CityGML data integration for modern urban challenges. Journal of Information Technology in Construction, ISSN 1874-4753.

Wakker, W. J., van der Molen, P. and Lemmen, C., 2003. Land registration and cadastre in the Netherlands, and the role of cadastral boundaries: The application of GPS technology in the survey of cadastral boundaries, Journal of Geospatial Engineering, 5:1, 3-10. 